\title{
CULTURAL AND HISTORICAL PREREQUISITES FOR THE DEVELOPMENT OF THE INNOVATIVE POTENTIAL OF THE SUBJECT OF CREATIVITY
}

\author{
${ }^{1}$ Jurayeva Sohibjamol Norkobilovna, ${ }^{2}$ Kiyamov Nishon Sadikovich, \\ ${ }^{3}$ Shodiev Fakhriddin Teshaevich, ${ }^{4}$ Suyarova Lola Gulmurodovna, ${ }^{5}$ Sultonov Akram Ikromovich \\ ${ }^{1}$ Candidate of Psychological Sciences, Associate Professor, Tashkent State Agrarian University, Tashkent, Uzbekistan. \\ ${ }^{2}$ Doctor of pedagogical Sciences, Associate Professor of the Department of Pedagogy, Samarkand State University, Tashkent, \\ Uzbekistan. \\ ${ }^{3}$ Candidate of Philological Sciences, Associate Professor, Head of the Department of Theory and Practice of Primary Education, \\ Samarkand State University, Tashkent, Uzbekistan. \\ ${ }^{4}$ Teacher of the Department of Distance Education, Samarkand State University, Tashkent, Uzbekistan. \\ ${ }^{5}$ Teacher of Karshi State University, Tashkent, Uzbekistan.
}

\begin{abstract}
:
This article details in detail the creativity of the creator in the world and through the history and culture of the world, the essence of which is the method of existence of the creator in the world, its innovative potential, and the ideas of thinkers as cultural and historical sources for the innovative development of the subject of creativity. It is justified that pedagogical and psychological sciences play an important role in the development of the creative potential of the subject of creativity.

Keywords: innovative potential, subject, civilization, creativity, cultural and historical, theatrical play.

Article Received: 18 October 2020, Revised: 3 November 2020, Accepted: 24 December 2020
\end{abstract}

\section{Introduction}

The path of the creative subject in the world always runs through personal and world history and culture. S. L. Rubinstein wrote that "the subject as such is a way of being" [12, p. 59]. In essence, this means that the subject of creativity is a method of its existence in the world. Then the question arises: how does creativity exist in the world? I recall Shakespeare's definition of life, in which, of course, he had in mind the theatrical play, theater as a special unity of space, time and action. Howiscreativityinobjectivespace, timeandaction?

The world historically resists creativity; it would prefer custom-made creativity to any creativity out of freedom. The mystery of creativity translates into the drama of a human creator, it is tragic [3]. Thus, the innovative potential of the subject of creativity is the possibility of introducing new into the world through activity, that is, penetration into the bowels of the current existence, substantiation there and consolidation of the occupied cultural disposition. Formally, this is generally considered to be the functional achievement of the final utilitarian point of application of creativity (its practical use), a cultural product as an object accessible to mass consumption. As the heroes of the science fiction movie "Cloud Atlas" (2013) put it, "to the consumer of a new day". This exhausts the formal meaning of innovation, convenient and beneficial to representatives of modern information technology society [14].

Material and methods

In a primordially civilizational context, culture resembles the Tower of Babel: it is highly fragmented and aimed at self-destruction $[15, \mathrm{p}$. eleven]. "Our entire civilization is not viable, and the reason for this, as P. Russell noted, is the nonviability of our value system, our very consciousness, which determines our attitude to the world" [6, p. twenty]. Addressing the external, objective side of value, its stupefaction envelops the townsfolk, businessmen, politicians, economists, sociologists, and lawyers. The innovative potential of the subject of creativity, while continuing to be a "civilizational rivet", becomes an innovative shroud of spirituality in 
culture. On that stands modern Babylon. Such is the plan for solving the creative question in a civilizational context: "The psychology of creativity has turned into a conglomerate of knowledge" [11, p. 245]. However, "the most important and the most mysterious, the most creative new comes not from the" world ", but from the spirit" [1, p. 497].

\section{Results and discussion}

A different plan for solving the creative question is revealed when considering culture in the psychological-pedagogical context immanent to it. "Civilization has developed a number of higher ideas, feelings and aspirations: they must be in stock ..." - wrote D. N. Ovsyaniko-Kulikovsky [10, p. thirty]. The innovative potential of the subject of creativity in the presentation of pedagogy and psychology is primarily the potential of human freedom [8], which means that it carries fundamental ontological significance. "Creativity is the cultural equivalent of the process of genetic change, due to which biological evolution is accomplished" $[15$, p. 8]. This is noted by representatives of domestic and foreign psychological schools [2;13].

This is the freedom of searching and touching the new, its spontaneous experience. "Innovation is interpreted by us as a key creative ability and willingness to constantly and continuously ensure the positive (constructive) use, application of this novelty of knowledge for real-practical change, transformation (not only of things, but of all types of social relations)" [5, p. 47-48]. Expressed in the language of active psychology, this is the potential of a free person to act creatively, transforming the world, the potential of activities for the development of man and the world: "creativity appeared as a developing interaction, as an interaction leading to development" [11, p. 257]. So, "the results of creativity make our culture richer and indirectly increase the quality of our lives" [15, p. 12]. The subject of creativity is both a subject of culture and a subject of life (life activity), and this is an informal way of answering a creative question. L. S. Vygotsky said that "the desire of the imagination to realize ... is the true basis and driving principle of creativity. The whole construction of the imagination, based on reality, seeks to describe the full circle and become a reality "[4, p. 537].

The distinction between objectification (subject of culture) and incarnation (subject of life) of the new in creativity was made by N. A. Berdyaev [1]. Objectification leads to a new Babylon, embodiment to a new creative eon. Berdyaev connected the last movement with a special way of transcending in creativity, a value-semantic transition that raises the level of being [ibid.]. Developing the ideas of Vygotsky, V.P. Zinchenko noted that "thought does not fit in a word; thought and word are from the very beginning not at all tailored in one image ... "[7, p. 387].

But the personality does not fit in the subject, it is always higher and larger than the subject, overflows over its edges and is thought in a higher axiological and semantic framework. The innovative potential of the subject of creativity is the psychological field of the possibilities of the prophetic development of life. As D. A. Leontyev accurately put it, "as one ascends to more complex and more advanced forms and mechanisms of human life activity and psychological processes, their causes begin to be more and more replaced by prerequisites, which, unlike causes, generate not necessary consequences, but possibilities, then as their absence is impossibility "[9, p. 29].

Such is the plan for solving the creative question in the psychological and pedagogical context of understanding culture. The introduced results of creative activity enrich the existing world, replenishing the piggy bank of the cultural fund of mankind, and at the same time, they change the value plan of cultural activity (saturation of the creative field) and the existence of the subject of creativity (creature being). The personality is not limited to the creative act: behind it, behind the living real being of the subject of creativity, there is always a semantic subject, or rather, a transsubject, a semantic creator. Continuing 
Vygotsky's thought, let's say that a person is committed in the subject. A creative act (transaction) acquires an innovative achievement in culture. Therefore, the innovative potential of the subject of creativity is determined by the cultural and historical premises of life and is limited by the field of creativity, its subject, content, material and form.

Cultural and historical prerequisites for the development of the innovative potential of the subject of creativity in the era of uncertainty of the beginning

XXI centuries are:

1) spiritual, religious, mystical and philosophical ideas and models;

2) the existence of world art, literature, theater, music, architecture, sculpture and design;

3) life experience of personal creativity in various cultural fields;

4) a system of mythopoetic, symbolic, artistic, and generally aesthetic understanding of the subject of creativity;

5) worldview and historical-evolutionary prognostic scenes (functional-style, dramatic, play, fantastic, transactional, etc.) of the future life of man and the world.

\section{Conclusions}

Each of these prerequisites carries a whole range of opportunities for creative self-development of a person. As V.P. Zinchenko correctly noted, "when studying creativity one cannot limit oneself to any one of its sources, be it imagination (even transcendental), thinking, or even five muses, which poets call" the whole cause ". The presence of many sources of creativity - this is its heterogeneity "[7, p. 368]. When the possibility of a multiple beginning (or multiple beginnings) of creativity arises, of course, the possibility of its multiple ending (multiple finals) also appears. This means that the cultural and historical prerequisites for the development of the innovative potential of the subject of creativity give rise to a proving ground of meanings, in an era of change preventing the conversion of civilized Babylon to the ontological Necropolis.

\section{References}

[1] Berdyaev N. A. Spirit and reality / N. A. Berdyaev. - M.: Astrel, 2011 .-- 664 p.

[2] De Bono E. Think! It is not too late / E. de Bono; per. from English V. Kuzin. - SPb. : Peter, 2011 .-- 224 p.

[3] Vygotsky L. S. Psychology of art / L. S. Vygotsky. -M. : Art, 1968. - 576 p.

[4] Vygotsky L. S. Thinking and speech: collection / L. S. Vygotsky / comp. E. Red. - M.: AST, 2008 .-- 668 p.

[5] Gorbunov A.P. Transformational (creative-innovative) university as a response to the challenges of the new era / A.P. Gorbunov // Higher education in Russia. - 2013. - No. 8-9. - S. 42-59.

[6] Grof S. Revolution of consciousness: transatlantic dialogue / S. Grof,

[7] E. Laszlo, P. Russell; per. from English M. Drachinsky. - M.: AST, 2004 .-- 248 p.

[8] Zinchenko V.P. Consciousness and the creative act / V.P. Zinchenko. - M.: Languages of Slavic cultures, 2010 .-- 592 p.

[9] Kuzmina E. I. Psychology of freedom: theory and practice / E. I. Kuzmina. - SPb. : Peter, 2007 .-- 336 p.

[10] Personal potential: structure and diagnostics: monograph / ed. D.A. Leontiev. - M.: Sense, 2011 .-- 680 p.

[11] Ovsyaniko-Kulikovsky D. N. Psychology of thoughts and feelings: an introduction to an unwritten book on the psychology of mental creativity / D. N. OvsyanikoKulikovsky. - M.: Librocom, 2012 .-- 176 p.

[12] The psychology of creativity: the school of Y. A. Ponomarev / ed. D.V. Ushakova. M.: IP RAS, 2006 .-- 624 p.

[13] Rubinstein S. L. Man and the world / S. L. Rubinstein. - SPb. : Peter, 2012 --- 224 p.

[14] Creativity: from biological foundations to social and cultural phenomena / ed. D.V. Ushakova. - M.: IP RAS, 2011 .-- 736 p. 
[15] Fromm E. "To have" or "to be" / E. Fromm; per. with him. E. Telyatnikova. M.: AST Moscow, 2008 .-- 314 p.

[16] Chiksentmihayli M. Creativity. The stream and psychology of discoveries and inventions / M. Chiksentmihayli; per. from English I. Yushchenko. - M.: Career Press, 2013 -- 528 p. 